\title{
Postural body: a systematic review about assessment methods
}

\section{Postura corporal: uma revisão sistemática sobre métodos de avaliação}

\author{
Xavele Braatz Petermann', Estele Caroline Welter Meereis²
}

\begin{abstract}
Introduction: There are different methods for assessing body posture used in physiotherapeutic research, however, there is still no consensus on what would be the most widely used. Objective: Review the methods for body postural assessment used in research today. Method: A literature review was performed on Brazilian papers published from 2010 to 2014. This papers were found Virtual Health Library database, with Health Sciences Descriptors: posture and assessment. Results: Ten assessment methods were found, as follows: Postural Assessment Software (PAS), digital photography, photogrammetry, photography, Kendall et.al. method, Kendall et.al. method with photography, New York Postural Assessment method (NYPAM), biophotogrammetry, evaluation form, and posturograma. Among others, the most used method is PAS (15 papers), followed by Kendall et.al. method with photography (six papers). Conclusion: Various methods for body postural assessment are employed, among PAS show us that is the most used.
\end{abstract}

Keywords: Evaluation; Posture; Physical therapy specialty.

\section{RESUMO}

Introdução: Existem diferentes métodos para avaliação da postura corporal que são utilizados em pesquisas por fisioterapeutas, no entanto, ainda não existe um consenso sobre qual seria o método mais utilizado em estudos nesta área. Objetivo: Realizar uma revisão sobre métodos de avaliação da postura corporal utilizados em pesquisas na atualidade. Método: Foi realizada uma busca bibliográfica de artigos brasileiros publicados entre 2010 e 2014, na base de dados da Biblioteca Virtual em Saúde, com os Descritores em Ciências da Saúde: Postura e avaliação. Resultados: Foram encontrados 10 métodos de avaliação, sendo eles: Software para Avaliação Postural (PAS), Fotografia digital, Fotogrametria, Fotografia, Método de Kendall et al., Fotografia com método de Kendall et al., Método de Avaliação Postural de Nova York (MAPNY), Biofotogrametria, Ficha de avaliação e Posturograma. Dentre os métodos utilizados, o mais frequente foi o PAS (15 artigos), seguido da Fotografia com método de Kendall et al. (seis artigos). Conclusão: Foi verificado que são empregados diversos métodos para a avaliação da postura corporal, dentre os quais o PAS mostrou-se como o mais utilizado.

Palavras-chave: Avaliação; Postura; Fisioterapia.

Corresponding author: Estele Caroline Welter Meereis. Rua Rodolpho Paulo Rocco, 255, Cidade Universitária, Zip Code: 21941-913, Rio de Janeiro (RJ), Brazil. Phone: (21) 3938-2223. E-mail: estelemeereis@gmail.com

2 Universidade Federal do Rio de Janeiro (UFRJ), Rio de Janeiro (RJ), Brazil.

Full list of author information is available at the end of the article.

Financial support: None.

Submission date 28 November 2015; Acceptance date 08 February 2016; Publication date 26 February 2016 


\section{INTRODUCTION}

Posture is defined by Academia Americana de Ortopedia as an equilibrium state between muscles and bones with the ability of protecting from trauma other structures of the human body. ${ }^{(1)}$ According to Magee posture is composed of different positions of body's joints at a certain moment. ${ }^{(2)}$

There are many definitions of posture, but it should be emphasized that posture involves a dynamic relationship in which body parts, specially muscles, adapted in response to stimuli received, reflecting the lived experiences on the body. ${ }^{(1)}$

To evaluate postural alignment is necessary to be a standardization of posture. Standard posture is defined as one that involves a minimum effort and overload and leads to maximum efficiency of the body. ${ }^{(3)}$

In standard posture the spine presents normal curvatures and the bones of the lower limbs are in perfect alignment for weight bearing. The pelvis neutral position leads to good alignment of the abdomen, trunk and lower limbs. The chest and upper spine are in a position that promotes optimal function of the respiratory organs. The head is upright in a well-balanced position that minimizes the burden on the cervical muscles. ${ }^{(3)}$

When the individual is in upright position the rear of the skull, the back and the buttocks are tangent to a vertical plane, thus showing that the spine should be rectilinear in posterior plane. The sagittal plane has four curvatures: cervical lordosis, thoracic kyphosis, lumbar lordoses and sacral curvature. ${ }^{(4)}$

There are different methods for evaluation of body posture which are used in research by physiotherapists, however, there is no consensus on what would be the most widely used method in studies in this area. Thus, the aim of this article is to review about evaluation of body posture methods used in nowadays research.

\section{METHODS}

This study is characterized as a systematic review of articles published in the last five years (from 2010 to 2014) and indexed in the database of the Virtual Health Library (VHL). The terms used to search for articles, according to the Health Sciences Descriptors (DeCS), were: Posture and evaluation.

As inclusion criteria it was decided that the studies should deal with investigations into methods for assessing body posture, to be conducted by at least one physiotherapist and be published in Brazil. Exclusion criteria were: review articles, articles that did not have the full text available in the database and studies that only evaluated the posture of a body part. So, 33 articles about methods of assessment of body posture were selected for analysis, as can be seen in Figure 1.

\section{RESULTS}

From search, 33 studies were found, which are arranged in chronological order of publication in Table 1.

Ten evaluation methods were found, as follows: Postural Assessment Software (PAS), Digital photography, Photogrammetry, Photography, Method of Kendall et al., Photography with method of Kendall et al., New York Postural Assessment Method, Biophotogrammetry, Evaluation form and Posturograma. The frequency of use of these methods is illustrated in Figure 2.

Regarding the presentation of the data was also no standardization observed, as some studies showed quantitative values describing the angles related to the alignment of the body posture, while other studies conducted a qualitative analysis, describing the changes. In Figure 3, it can be seen the most frequent ways of presenting the data of the investigated studies.

About the studied population, studies were found with people of different age groups, as shown in Figure 4.

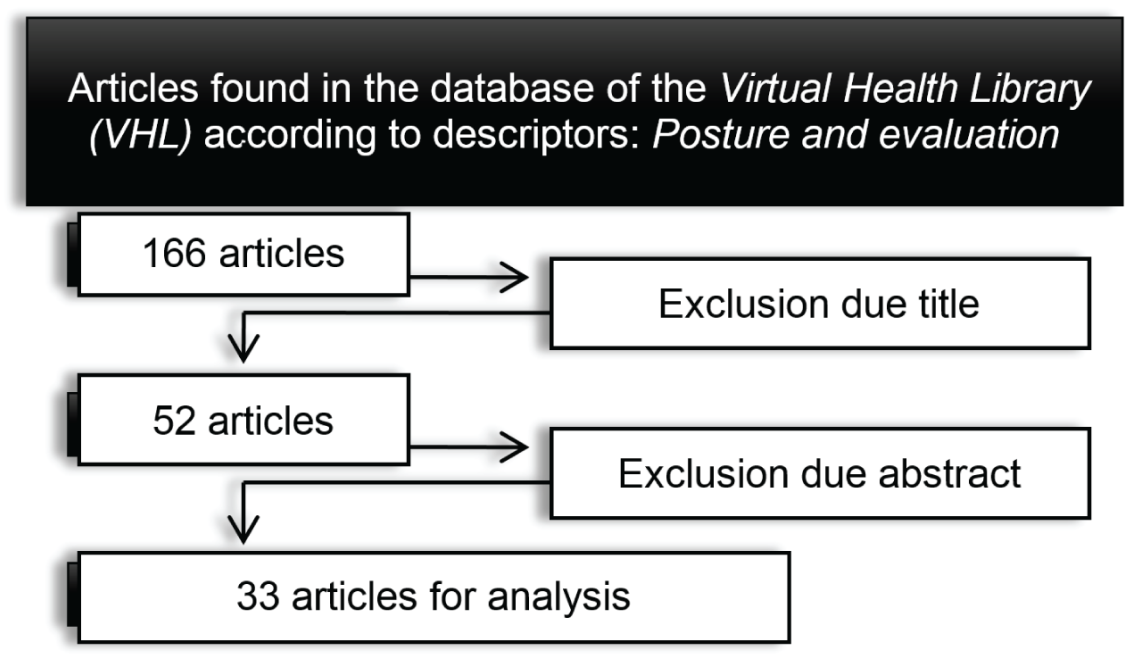

Figure 1. Selection of items searched in the electronic databases. 
Table 1. Summary of articles found.

\begin{tabular}{|c|c|c|c|c|c|c|}
\hline Author & Periodic & Study Theme & N sample & Individuals Age & Method Used & $\begin{array}{l}\text { Presentation Form } \\
\text { of Results }\end{array}$ \\
\hline Moraes et al. $2010^{(5)}$ & Fisioter. mov. (Impr.) & $\begin{array}{l}\text { Different type of } \\
\text { footwear and body } \\
\text { posture }\end{array}$ & 15 women & $23,2 \pm 3,36$ years & $\begin{array}{l}\text { Photogrammetry } \\
\left(\text { PAS }^{\circledR}\right)\end{array}$ & $\begin{array}{l}\text { Average and } \\
\text { standard deviation } \\
\text { of the measured } \\
\text { angles }\end{array}$ \\
\hline Lima et al. $2010^{(6)}$ & $\begin{array}{l}\text { Rev. bras. Educ. Fís. } \\
\text { Esporte }\end{array}$ & $\begin{array}{l}\text { Gymnastics } \\
\text { program, posture } \\
\text { and flexibility }\end{array}$ & 10 elderly & $67,5 \pm 5,76$ years & Digital photography & Frequency changes \\
\hline Bigaton et al. $2010^{(7)}$ & $\begin{array}{l}\text { Rev Soc Bras } \\
\text { Fonoaudiol. }\end{array}$ & $\begin{array}{l}\text { Posture and } \\
\text { function of the } \\
\text { cranio-cervical } \\
\text { region }\end{array}$ & $\begin{array}{l}28 \text { dysphonic } \\
\text { women }\end{array}$ & $31,25 \pm 8,14$ years & Photogrammetry & $\begin{array}{l}\text { Average and } \\
\text { standard deviation } \\
\text { of the measured } \\
\text { angles }\end{array}$ \\
\hline $\begin{array}{l}\text { Coelho Júnior et al. } \\
2010^{(8)}\end{array}$ & Rev Bras Fisioter & $\begin{array}{l}\text { Head and shoulders } \\
\text { alignment in } \\
\text { patients with } \\
\text { unilateral vestibular } \\
\text { hypofunction (UVH) }\end{array}$ & $\begin{array}{l}30 \text { individuals } \\
\text { with UVH and } 30 \\
\text { individuals with } \\
\text { normal vestibular } \\
\text { function and } \\
\text { without complaints } \\
\text { of dizziness }\end{array}$ & $\begin{array}{l}\text { Study group } 52,63 \\
\pm 6,97 \text { years and } \\
\text { control group } 52,13 \\
\pm 7,25 \text { years }\end{array}$ & $\begin{array}{l}\text { Photography, } \\
\text { Kendall et al. e } \\
\text { Magee }\end{array}$ & $\begin{array}{l}\text { Average, standard } \\
\text { deviation, median } \\
\text { and percentiles of } \\
\text { the angles }\end{array}$ \\
\hline Graup et al. $2010^{(9)}$ & Rev Bras Ortop. & $\begin{array}{l}\text { Sagittal postural } \\
\text { changes in the } \\
\text { lumbar spine in } \\
\text { students }\end{array}$ & $\begin{array}{l}288 \text { teens, } \\
156 \text { male and } 132 \\
\text { female }\end{array}$ & $\begin{array}{l}\text { Male } 16 \pm 1,06 \\
\text { years and female } \\
15,87 \pm 1,05 \text { years }\end{array}$ & Photogrammetry & Percentage changes \\
\hline $\begin{array}{l}\text { Molinari et al. } \\
2010^{(10)}\end{array}$ & Health Sci Inst & $\begin{array}{l}\text { Posture and plantar } \\
\text { support }\end{array}$ & $\begin{array}{l}20 \text { obese children } \\
\text { with Down } \\
\text { Syndrome }\end{array}$ & $\begin{array}{l}\text { The average age } \\
\text { was } 10.3 \text { years } \\
\text { (G1) and } 10.5 \text { years } \\
\text { (G2), with extremes } \\
\text { between nine and } \\
\text { twelve years. }\end{array}$ & $\begin{array}{l}\text { Photography } \\
\text { Kendall et al. }\end{array}$ & Frequency changes \\
\hline Okama et al. $2010^{(11)}$ & ConScientiae Saúde & $\begin{array}{l}\text { Posture in the } \\
\text { patients bearers } \\
\text { of Duchenne and } \\
\text { Becker Muscular } \\
\text { Distrophy }\end{array}$ & 13 patients & $16,75( \pm 6,9)$ years & $\begin{array}{l}\text { Photogrammetry } \\
\text { (PAS) }\end{array}$ & Dendogram \\
\hline $\begin{array}{l}\text { Vasconcelos et al. } \\
(2010)^{12}\end{array}$ & Fisioter. mov. (Impr.) & $\begin{array}{l}\text { Postural changes } \\
\text { of the spine in } \\
\text { students }\end{array}$ & 32 deaf students & $\begin{array}{l}\text { Aged between } 7 \text { to } \\
21 \text { years }\end{array}$ & Kendall et al. & Frequency changes \\
\hline $\begin{array}{l}\text { Ferreira et al. } \\
2011^{(13)}\end{array}$ & Distúrb Comun & $\begin{array}{l}\text { Voice and posture } \\
\text { of teachers }\end{array}$ & $\begin{array}{l}4 \text { University } \\
\text { Professors }\end{array}$ & 28 and 45 years & $\begin{array}{l}\text { Photogrammetry } \\
\text { (PAS) }\end{array}$ & $\begin{array}{l}\text { Descriptive analysis } \\
\text { of changes }\end{array}$ \\
\hline $\begin{array}{l}\text { Machado et al. } \\
2011^{(14)}\end{array}$ & Rev. CEFAC & $\begin{array}{l}\text { Voice and posture } \\
\text { of aqua aerobics } \\
\text { teachers }\end{array}$ & $\begin{array}{l}14 \text { women and } 03 \\
\text { men }\end{array}$ & $\begin{array}{l}\text { The age of } \\
\text { individuals ranged } \\
22-55 \text { years with an } \\
\text { average of } 31.33 \\
\text { years for males and } \\
31.1 \text { for females }\end{array}$ & Kendal et al. & $\begin{array}{l}\text { Average and } \\
\text { standard deviation }\end{array}$ \\
\hline $\begin{array}{l}\text { Meereis et al. } \\
2011^{(15)}\end{array}$ & $\begin{array}{l}\text { R. da Educação } \\
\text { Física/UEM }\end{array}$ & $\begin{array}{l}\text { Postural changes } \\
\text { in classical ballet } \\
\text { dancers }\end{array}$ & 10 ballet dancers & $\begin{array}{l}\text { Average } \pm \text { DP: } 15,7 \\
\pm 2,2 \text { Median (P25 } \\
-75): 16,0(14,0- \\
17,8)\end{array}$ & $\begin{array}{l}\text { Photogrammetry } \\
\text { (PAS) }\end{array}$ & $\begin{array}{l}\text { Frequency; } \\
\text { Average; Standard } \\
\text { Deviation; Median } \\
\text { (Interquartile range) } \\
\text { of measured angles }\end{array}$ \\
\hline Conti et al. $2011^{(16)}$ & J. Pediatr. & $\begin{array}{l}\text { Body posture and } \\
\text { mouth breathing } \\
(\mathrm{MBr})\end{array}$ & $\begin{array}{l}306 \mathrm{MBr} \text { (mouth } \\
\text { breathing group) e } \\
124 \mathrm{NBr} \text { (healthy } \\
\text { group) }\end{array}$ & $\begin{array}{l}\text { Children and teens } \\
5-14 \text { years }\end{array}$ & $\begin{array}{l}\text { New York postural } \\
\text { assessment method }\end{array}$ & $\begin{array}{l}\text { Body posture } \\
\text { classification } \\
\text { (Normal, Moderate } \\
\text { and Severe) }\end{array}$ \\
\hline $\begin{array}{l}\text { Souza Melo et al. } \\
2011^{(17)}\end{array}$ & $\begin{array}{l}\text { Arq. int. } \\
\text { otorrinolaringol. } \\
\text { (Impr.) }\end{array}$ & $\begin{array}{l}\text { Posture of the } \\
\text { spine and hearing } \\
\text { impairment in } \\
\text { students }\end{array}$ & 44 students & $\begin{array}{l}\text { Average age } 12 \pm 3,2 \\
\text { years }\end{array}$ & $\begin{array}{l}\text { Photography, } \\
\text { Kendall et al. and } \\
\text { Kisner and Colby }\end{array}$ & Frequency changes \\
\hline
\end{tabular}


Table 1. Continued...

\begin{tabular}{|c|c|c|c|c|c|c|}
\hline Author & Periodic & Study Theme & N sample & Individuals Age & Method Used & $\begin{array}{c}\text { Presentation Form } \\
\text { of Results }\end{array}$ \\
\hline Melo et al. $2011^{(18)}$ & Rev. bras. cancerol & $\begin{array}{l}\text { Posture and } \\
\text { modified radical } \\
\text { mastectomy surgery }\end{array}$ & 22 women & $\begin{array}{l}\text { Average age } \\
53,8 \pm 6,6 \text { (DP) years }\end{array}$ & $\begin{array}{l}\text { Photogrammetry } \\
\text { (PAS) }\end{array}$ & $\begin{array}{l}\text { Average and } \\
\text { standard deviation } \\
\text { of measured angles }\end{array}$ \\
\hline Rossi et al. $2011^{(19)}$ & Fisioter. mov. & $\begin{array}{l}\text { Global Postural } \\
\text { Re-education and } \\
\text { posture }\end{array}$ & $\begin{array}{l}30 \text { voluntary } \\
\text { women }\end{array}$ & $20 \pm 2,4$ years & $\begin{array}{l}\text { Photogrammetry } \\
\text { (PAS) }\end{array}$ & $\begin{array}{l}\text { Average and } \\
\text { Standard deviation }\end{array}$ \\
\hline $\begin{array}{l}\text { Candotti et al. } \\
2011^{(20)}\end{array}$ & Rev Paul Pediatr & $\begin{array}{l}\text { Postural education } \\
\text { program and } \\
\text { posture }\end{array}$ & 34 participants & $\begin{array}{l}\text { Children } 10,5 \pm 0,8 \\
\text { years; teens } 13,2 \pm \\
1,0 \text { years }\end{array}$ & $\begin{array}{l}\text { Photography } \\
\text { Kendall et al. }\end{array}$ & $\begin{array}{l}\text { Average and } \\
\text { Standard deviation }\end{array}$ \\
\hline $\begin{array}{l}\text { Meliscki et al. } \\
2011^{(21)}\end{array}$ & Fisioter. mov. & $\begin{array}{l}\text { Posture and type } \\
\text { of breathing in } \\
\text { swimming athletes }\end{array}$ & $\begin{array}{l}60 \text { athletes: } \\
29 \text { women and } 31 \\
\text { men }\end{array}$ & $\begin{array}{l}\text { Men } 19,2 \pm 2,7 \\
\text { years; women } 19,2 \\
\pm 3,8 \text { years }\end{array}$ & Photography & $\begin{array}{l}\text { Descriptive analysis } \\
\text { and frequency } \\
\text { changes }\end{array}$ \\
\hline Veiga et al. 2011(22) & $\begin{array}{l}\text { Rev. Bras. Ciênc. } \\
\text { Esporte (Impr.) }\end{array}$ & $\begin{array}{l}\text { Sports injuries, } \\
\text { postural changes } \\
\text { and flexibility of the } \\
\text { posterior chain }\end{array}$ & 28 male athletes & $\begin{array}{l}\text { Aged between } 17 \text { to } \\
20 \text { years }\end{array}$ & Photogrammetry & $\begin{array}{l}\text { Descriptive analysis } \\
\text { of changes }\end{array}$ \\
\hline $\begin{array}{l}\text { Pachioni et al. } \\
2011^{(23)}\end{array}$ & Fisioter. Pesqui. & $\begin{array}{l}\text { Postural changes } \\
\text { and Chronic } \\
\text { Obstructive } \\
\text { Pulmonary Disease }\end{array}$ & 30 individuals & $\begin{array}{l}\text { Control group age } \\
70 \pm 7 \text { years and } \\
\text { COPD group age } 70 \\
\pm 8 \text { years }\end{array}$ & $\begin{array}{l}\text { Photogrammetry } \\
\text { (PAS) }\end{array}$ & $\begin{array}{l}\text { Median and } \\
\text { interquartile range } \\
\text { of measured angles }\end{array}$ \\
\hline $\begin{array}{l}\text { Gasparotto et al. } \\
2012^{(24)}\end{array}$ & $\begin{array}{l}\text { Ciênc. saúde } \\
\text { coletiva }\end{array}$ & $\begin{array}{l}\text { Posture to self- } \\
\text { perception }\end{array}$ & 18 elderly & $\begin{array}{l}\text { Aged between } 62 \text { to } \\
83 \text { years, average of } \\
70 \text { years }\end{array}$ & $\begin{array}{l}\text { Photography } \\
\text { Kendall et el. }\end{array}$ & $\begin{array}{l}\text { Descriptive analysis } \\
\text { of changes }\end{array}$ \\
\hline $\begin{array}{l}\text { Bosso et al. } \\
2012^{(25)}\end{array}$ & $\begin{array}{l}\text { Rev. Bras. Med. } \\
\text { Esporte }\end{array}$ & $\begin{array}{l}\text { Postural changes in } \\
\text { rhythmic gymnastics } \\
\text { athletes }\end{array}$ & 27 individuals & $\begin{array}{l}\text { Aged between } 7 \text { to } \\
15 \text { years, average of } \\
10,4 \text { years }\end{array}$ & $\begin{array}{l}\text { Photogrammetry } \\
\text { (PAS) }\end{array}$ & $\begin{array}{l}\text { Average, standard } \\
\text { deviation, median, } \\
\text { minimum and } \\
\text { maximum of } \\
\text { measured angles }\end{array}$ \\
\hline $\begin{array}{l}\text { Morimoto et al. } \\
2012^{(26)}\end{array}$ & Fisioter. mov. & $\begin{array}{l}\text { Postural changes } \\
\text { and mouth } \\
\text { breathing in } \\
\text { students }\end{array}$ & 117 children & $\begin{array}{l}\text { Average age } 9,017 \pm \\
0,851 \text { years }\end{array}$ & $\begin{array}{l}\text { Photogrammetry } \\
\text { (PAS) }\end{array}$ & $\begin{array}{l}\text { Average and } \\
\text { standard deviation }\end{array}$ \\
\hline Porto et al. $2012^{(27)}$ & Motriz: rev. educ. fis & $\begin{array}{l}\text { Postural profile in } \\
\text { the sagittal plane of } \\
\text { elderly }\end{array}$ & $\begin{array}{l}\text { Multidimensional } \\
\text { Senior Study Group } \\
\text { of Porto Alegre: } 272 \\
\text { elderly. Program of } \\
\text { Physical Exercise } \\
\text { Group: } 29 \text { elderly }\end{array}$ & $\begin{array}{l}\text { Multidimensional } \\
\text { Senior Study Group } \\
\text { of Porto Alegre: } \\
68,23 \pm 5,49 \text { years. } \\
\text { Program of Physical } \\
\text { Exercise Group: } \\
67,18 \pm 6,12 \text { years }\end{array}$ & $\begin{array}{l}\text { Photography } \\
\text { Kendall et al. }\end{array}$ & $\begin{array}{l}\text { Frequency of } \\
\text { changes }\end{array}$ \\
\hline
\end{tabular}

\begin{tabular}{|c|c|c|c|c|c|c|}
\hline Vieira et al. $2013^{(28)}$ & Pediatr. Mod. & $\begin{array}{l}\text { Posture and lung } \\
\text { parameters in } \\
\text { children with } \\
\text { bronchopulmonary } \\
\text { dysplasia history } \\
\text { and healthy children }\end{array}$ & 18 children & $\begin{array}{l}\text { Aged between } 6 \text { to } \\
12 \text { years }\end{array}$ & $\begin{array}{l}\text { New York postural } \\
\text { assessment }\end{array}$ & $\begin{array}{l}\text { Average, standard } \\
\text { deviation, median } \\
\text { and percentiles of } \\
\text { the angles }\end{array}$ \\
\hline $\begin{array}{l}\text { Tavares et al. } \\
2013^{(29)}\end{array}$ & $\begin{array}{l}\text { Scientia Medica } \\
\text { (Porto Alegre) }\end{array}$ & $\begin{array}{l}\text { Elderly posture and } \\
\text { physical activity }\end{array}$ & $\begin{array}{l}40 \text { elderly, } 34 \\
\text { women e } 6 \text { men }\end{array}$ & $68,5 \pm 5,1$ years & $\begin{array}{l}\text { Photogrammetry } \\
\text { (PAS) }\end{array}$ & $\begin{array}{l}\text { Average and } \\
\text { standard deviation } \\
\text { of measured angles }\end{array}$ \\
\hline Simão et al. $2013^{(30)}$ & Rev. CEFAC & $\begin{array}{l}\text { Posture, breathing } \\
\text { and swallowing } \\
\text { in post-accident } \\
\text { cerebrovascular } \\
\text { patients in the } \\
\text { chronic phase }\end{array}$ & 1 patient & 37 years & $\begin{array}{l}\text { Photogrammetry } \\
\text { (PAS) }\end{array}$ & $\begin{array}{l}\text { Descriptive analysis } \\
\text { of changes }\end{array}$ \\
\hline $\begin{array}{l}\text { Sinzato et al. } \\
(2013)^{31}\end{array}$ & Fisioter Pesq. & $\begin{array}{l}\text { Ground pilates } \\
\text { method, postural } \\
\text { alignment and joint } \\
\text { flexibility }\end{array}$ & 33 women & $\begin{array}{l}\text { Aged between } 18 \text { to } \\
30 \text { years }\end{array}$ & $\begin{array}{l}\text { Photogrammetry } \\
\text { (PAS) }\end{array}$ & $\begin{array}{l}\text { Variable, average } \\
\text { and standard } \\
\text { deviation of } \\
\text { measured angles }\end{array}$ \\
\hline
\end{tabular}


Table 1. Continued...

\begin{tabular}{|c|c|c|c|c|c|c|}
\hline Author & Periodic & Study Theme & N sample & Individuals Age & Method Used & $\begin{array}{c}\text { Presentation Form } \\
\text { of Results }\end{array}$ \\
\hline $\begin{array}{l}\text { Barbosa et al. } \\
2013^{(32)}\end{array}$ & $\begin{array}{l}\text { Rev. Bras. Ginecol. } \\
\text { Obstet. }\end{array}$ & $\begin{array}{l}\text { Body posture and } \\
\text { breast cancer }\end{array}$ & 39 women & $\begin{array}{l}\text { Average age } 50 \pm \\
10,5 \text { years }\end{array}$ & Biophotogrammetry & $\begin{array}{l}\text { Average and } \\
\text { standard deviation } \\
\text { of measured angles }\end{array}$ \\
\hline Borges et al. $2013^{(33)}$ & Acta Ortop Bras. & $\begin{array}{l}\text { Plantar arch, lumbar } \\
\text { curvature and } \\
\text { backaches }\end{array}$ & 18 women & $\begin{array}{l}\text { Average age } 30,45 \\
( \pm 6,25) \text { years }\end{array}$ & $\begin{array}{l}\text { Photogrammetry } \\
\text { (PAS) }\end{array}$ & $\begin{array}{l}\text { Measured angles } \\
\text { (lumbar angle) }\end{array}$ \\
\hline Colpo et al. $2013^{(34)}$ & Rev. dor & $\begin{array}{l}\text { Aqua aerobics, } \\
\text { subjective pain } \\
\text { perception and } \\
\text { their influence on } \\
\text { activities of daily } \\
\text { living, posture and } \\
\text { physical fitness }\end{array}$ & 20 women & $42,45 \pm 6,09$ years & $\begin{array}{l}\text { Observation of } \\
\text { Evaluation sheet }\end{array}$ & $\begin{array}{l}\text { Qualitative } \\
\text { description, only } \\
\text { the most incidents } \\
\text { deviations were } \\
\text { cited }\end{array}$ \\
\hline Azato et al. $2013^{(35)}$ & Rev. dor & $\begin{array}{l}\text { Temporomandibular } \\
\text { dysfunction and } \\
\text { overall posture of } \\
\text { individuals }\end{array}$ & 30 patients & $\begin{array}{l}\text { No age was } \\
\text { described }\end{array}$ & $\begin{array}{l}\text { Photogrammetry } \\
\text { (PAS) }\end{array}$ & $\begin{array}{l}\text { Average and } \\
\text { standard deviation } \\
\text { of the measured } \\
\text { angles }\end{array}$ \\
\hline $\begin{array}{l}\text { Haddad et al. } \\
2013^{(36)}\end{array}$ & Einstein (São Paulo) & $\begin{array}{l}\text { Postural and } \\
\text { upper limb range } \\
\text { of motion in } \\
\text { post-mastectomy } \\
\text { women, } \\
\text { lymphadenectomy } \\
\text { and radiotherapy }\end{array}$ & $\begin{array}{l}16 \text { post-mastectomy } \\
\text { women with } \\
\text { lymphedema and } \\
14 \text { post-mastectomy } \\
\text { women without } \\
\text { lymphedema }\end{array}$ & $\begin{array}{l}18 \text { to } 70 \text { years; } \\
M L=58,9 \text { e } M=59,7\end{array}$ & $\begin{array}{l}\text { Posturograma } \\
\text { Clinical, } \\
\text { Fisiometer }{ }^{\circledR} \text {, version } \\
2.8\end{array}$ & $\begin{array}{l}\text { Descriptive analysis } \\
\text { and frequency of } \\
\text { changes in each } \\
\text { group }\end{array}$ \\
\hline $\begin{array}{l}\text { Gimenes et al. } \\
2013^{(37)}\end{array}$ & J Health Sci Inst & $\begin{array}{l}\text { Water and ground } \\
\text { physical therapy in } \\
\text { posture of women } \\
\text { with mastectomies. }\end{array}$ & 15 patients & $\begin{array}{l}37 \text { to } 68 \text { years, } \\
\text { control group } \\
\text { average } 54,8 \text { years } \\
\text { and study group } \\
\text { average } 10,3 \text { and } \\
16,3 \text { years }\end{array}$ & $\begin{array}{l}\text { Photogrammetry } \\
\text { (PAS) }\end{array}$ & $\begin{array}{l}\text { Average, median } \\
\text { and standard } \\
\text { deviation of the } \\
\text { measured angles }\end{array}$ \\
\hline
\end{tabular}

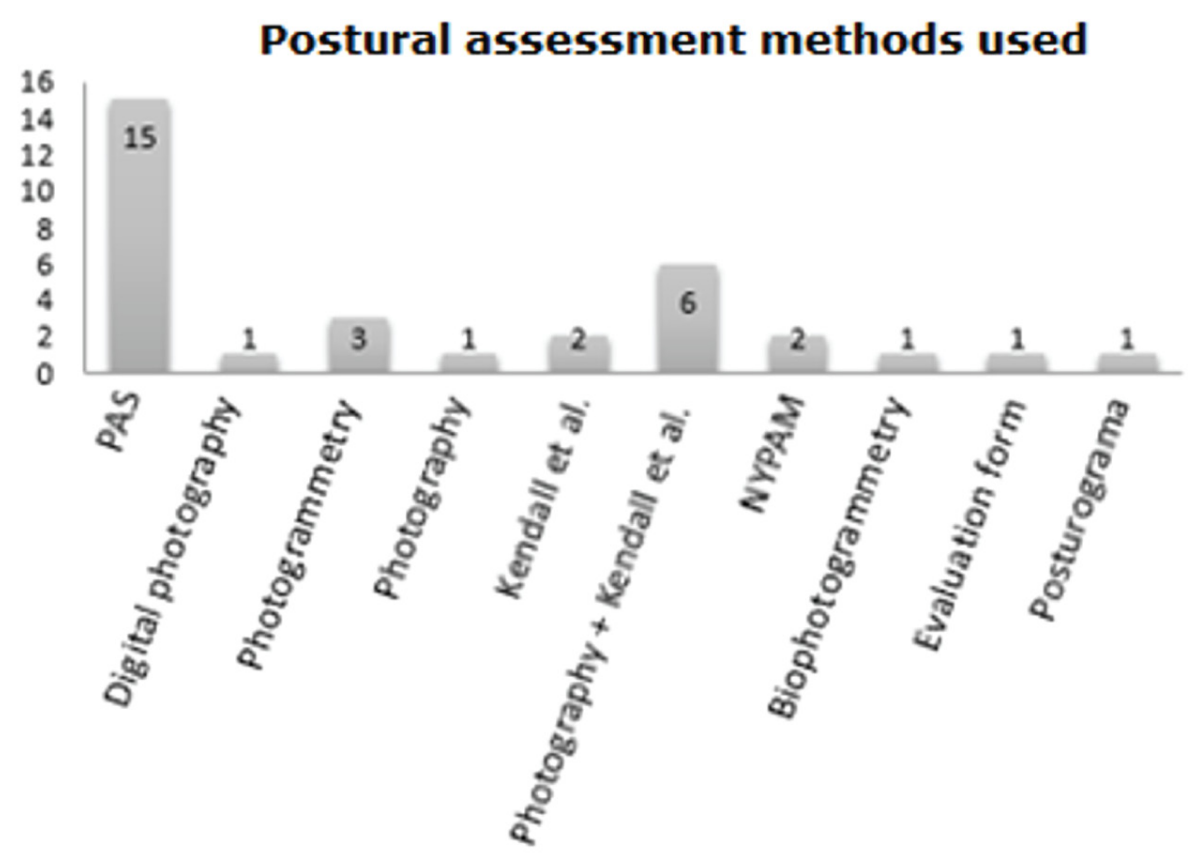

Figure 2. Frequency of methods used in the evaluation of body posture. Legend: PAS: Postural Assessment Software. NYPAM: New York Postural Assessment Method. 


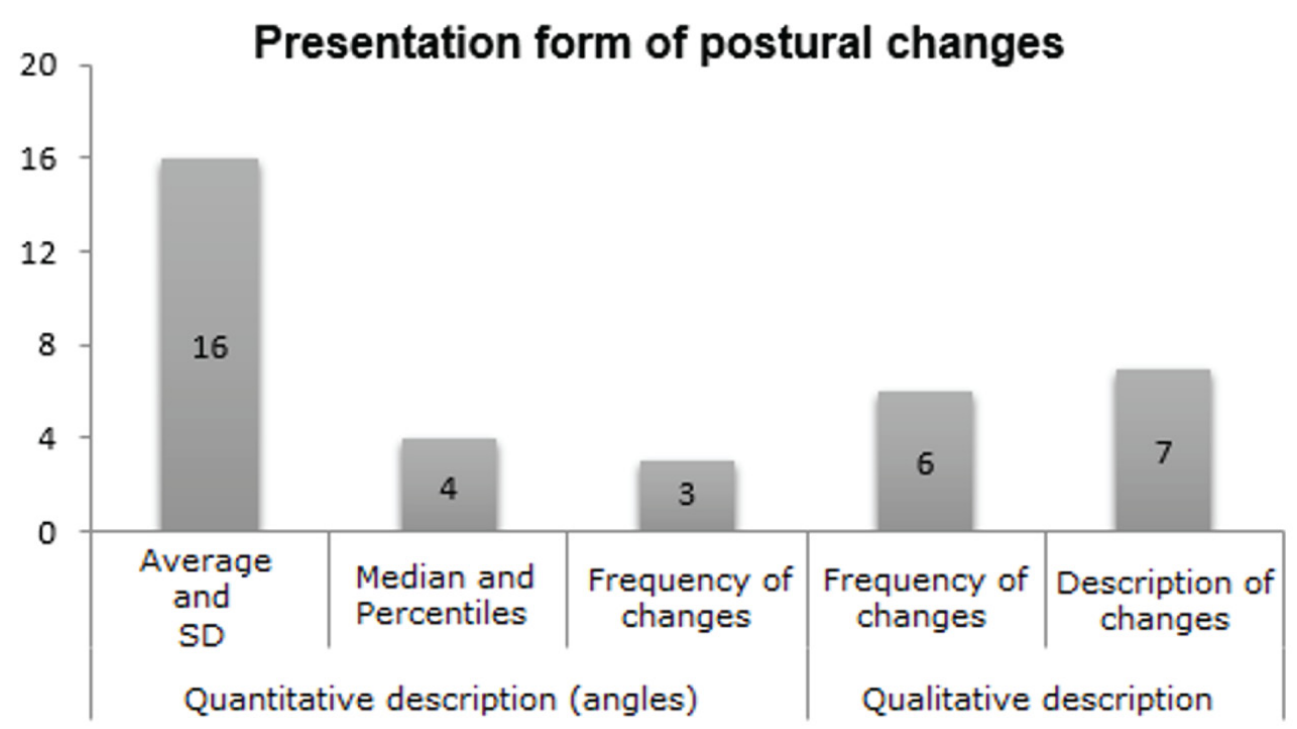

Figure 3. Frequency of presentation forms of results. Legend: SD: Standard Deviation

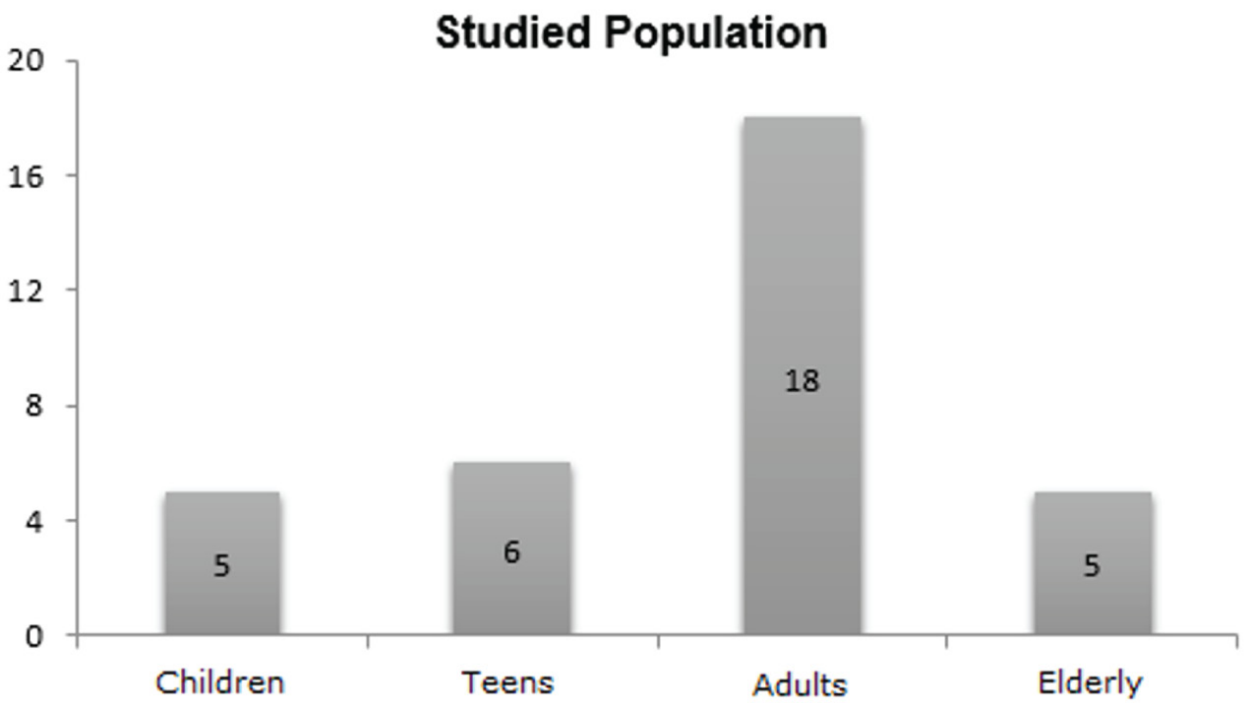

Figure 4. Frequency of studied population.

\section{DISCUSSION}

We found 33 studies that assessed body posture. The methods used for the evaluation of body posture were many, as the approached theme, the population and the presentation of the results of each study.

The methods used in the studies were:

a) Postural Assessment Software (PAS) was used in 15 studies: Moraes et al. ${ }^{(5)}$, Okama et al. ${ }^{(11)}$, Ferreira et al. ${ }^{(13)}$, Meereis et al. ${ }^{(15)}$, Melo et al. ${ }^{(18)}$, Rossi et al. ${ }^{(19)}$, Pachioni et al. ${ }^{(23)}$, Bosso et al. ${ }^{(25)}$, Morimoto et al. ${ }^{(26)}$, Tavares et al. ${ }^{(29)}$, Simão et al. ${ }^{\left({ }^{(3)}\right)}$, Sinzato et al. ${ }^{(31)}$, Borges et al. ${ }^{(33)}$, Azato et al. ${ }^{(35)}$, Gimenes et al. ${ }^{(37)}$.

This method consists of a computer program that, after the acquisition of photographs of subjects wearing swimsuits, marked in specific anatomical points and photographed from a distance of three meters, next to a plumb line and subsequent scan to these images to measure: position, length, angle and alignment of the body segments of a person, which allows analyzing the static posture in frontal, posterior and lateral right and left players. ${ }^{(5)}$

Braz, Goes, Carvalho (38) demonstrated validity and reliability of PAS program when performing repeated measurements by three evaluators without obtaining substantial differences in 15 different angular measurements. In Souza et al. ${ }^{(39)}$ study is described that photogrammetry determines a two-dimensional quantification of the body and the change of posture can be hidden by the evaluated plan. It is believed that this method should not replace clinical judgment, but complement it. It has been as positive 
aspects of PAS software protocol its practicality, the ability to standardize the measurements and the comparison between studies. The negative points relate to the assessment profile, especially regarding the curvatures of the spine, which are best seen in postural clinical outcome. This situation, however, does not compromise the PAS program, but it is recommended additional analysis to the PAS software protocol for mainly sagittal plane.

b) Photography and Kendall et al. method was used in 6 studies: Coelho Júnior et al. ${ }^{(8)}$, Molinari et al. ${ }^{(10)}$, Candotti et al. (20), Souza Melo et al.(17), Gasparotto et al. ${ }^{(24)}$, Porto et al. ${ }^{(27)}$. In the study of Coelho Júnior et al. (8) was also used Magee (2) and in the article of Souza Melo et al. (17) was used Kisner and Colby (40).

For this evaluation we use a symmetrograph. The assessed individual is positioned behind this equipament in standing position and without dress and bare feet, while the evaluator, situated in front of the simetograph, performs the photograph. It is requested that the individual remains naturally standing (27). The camera was positioned on a tripod, perpendicular to simetograph in the distance of $1.80 \mathrm{~m}$, allowing the capture of the image of the entire volunteer body. Image analysis was based on the protocol described by Kendall et al. (3), which classifies the position in four different alignments: ideal alignment, flat back, kyphosis/lordosis and sway back. Thus, each volunteer photography was compared to images of the alignments of the Protocol.

c) Kendall et al. method was used in 2 studies: Vasconcelos et al. ${ }^{(12)}$, Machado et al. ${ }^{(14)}$.

In postural assessment is observed the individual in anterior view, profile and posterior view. In anterior view is observed the head position, the height difference of the shoulders, which could indicate a scoliosis. The same for the heights of the iliac crests. Check if the legs and knees bow out (genu varum) or if your knees touch while the ankles are separated (genu valgum). ${ }^{(3)}$

In profile test is assesses head position again, shoulder girdle (shoulders), abdomen, hips, cervical spine, lumbar, dorsal, sacrum and knees. The dorsal region more convex indicates accentuation of kyphosis and the reverse in lower back indicates accentuation of lumbar lordosis. Very preceding shoulders indicate protrusion of shoulders. Knees very curved back indicate genu-recurvatum. ${ }^{(3)}$

On examination of the posterior view of the right and left halves must be symmetrical. The hindfoot must have symmetrical support, not supported very medial or lateral; calcaneus should be in vertical alignment with the Achilles tendon; medial malleolus should be of equal height on both sides; popliteal fossa, as well as the gluteal folds, should be of equal height; pelvis should be of equal height on both sides, with the anterior posterior iliac spines leveled on the horizontal plane; column must be aligned without presenting lateral deviations; Thales triangle should be symmetrical; shoulder blades should be equidistant from the spine and flattened against the rib cage; inferior angle of the scapula should lie flat in the horizontal plane; shoulders should be of equal height; head and neck should be straight, with no inclination or side rotation. (3)

d) Photogrammetry was used $\mathrm{n} 3$ studies: Bigaton et al. ${ }^{(7)}$, Graup et al. ${ }^{(9)}$, Veiga et al. ${ }^{(22)}$.

According to Graup et al. (9), in this method is used photographic images from a digital camera. It allows scanning in a program with graphical software in which it is possible to identify the angle generated by the intersection of anatomical points. In this study the camera was placed on a tripod 1.20 meters above the ground and 3 meters from the individuals.

e) New York State Postural Assessment Method was used in 2 studies: Conti et al. ${ }^{(16)}$, Vieira et al. ${ }^{(28)}$.

This method objectively assesses 13 different body segments. It features a scoring system for quantitative analysis of body posture. Posture is classified with the following scores: 5.0 for the normal pattern; 3.0 to moderate postural change; and 1.0 for severe postural change. ${ }^{(28)}$

f) Digital photography was used in 1 study: Lima et al. ${ }^{(6)}$.

In this method the symmetrograph is positioned in the background of photo and the plumb line between the individual and the camera (the plumb line is positioned slightly passing in front of the lateral malleolus right of the individual). The camera is positioned at a height of $0,78 \mathrm{~m}$ and a perpendicular distance of $2,56 \mathrm{~m}$ to the symmetrograph. The individual was placed in orthostatic position in profile to the evaluator, which recorded the posture through photographs. ${ }^{(6)}$

g) Photography was used in 1 study: Meliscki et al. ${ }^{(21)}$.

In this evaluation was used a digital camera and a tripod. The postural evaluation was performed in anterior and posterior view and right and left profile. The photographs were obtained in isolated room, with the participants wearing appropriate clothing for the exam. The camera was positioned on a tripod at a distance of $4 \mathrm{~m}$, and this evaluation was performed by a qualified physiotherapist. ${ }^{(21)}$

h) Biophotogrammetry was used in 1 study: Barbosa et al. ${ }^{(32)}$.

The images were acquired with the use of a camera positioned on a tripod with $1 \mathrm{~m}$ tall. The volunteers were in appropriate costumes, positioned on a mark drawn on the ground with their feet parallel, at a distance of $2.2 \mathrm{~m}$ from the camera in anterior and posterior views. For image processing was used CorelDraw ${ }^{\circledR}$ Software. ${ }^{(32)}$

i) Evaluation sheet- observation was used in 1 study: Colpo et al. ${ }^{(34)}$.

The evaluation was conducted through observation, using as a benchmark the posturography test in which the individual is wearing swimsuits and barefoot. ${ }^{(34)}$

j) Clinical Posturogram was used in 1 study: Haddad et al. ${ }^{(36)}$.

Posture assessment was performed with the capture of six images with the individual in orthostatic position (ventral 
and back sides, left and right profile) and anterior trunk flexion (anterior and lateral views). The postural evaluation program, named as clinical posturogram, issues reports with photos and graphic evaluation. All these data were analyzed quantitatively because the software performs exact averages between anatomical points marked on the assessed individual (acromion; anterior superior iliac spine; lateral malleolus; inferior angle of the scapula; posterior superior iliac spine and glabella. For range of motion assessments were checked: surface projection of the center of the glenohumeral joint laterally; greater and lesser tubercle of the humerus; center of the olecranon; styloid process of the ulna; acromion; surface projection of the center of the elbow joint; center between radius and ulna distally). ${ }^{(36)}$

Considering the analysis methods used, it can be seen that there was no uniformity in the choice of the method for the evaluation of body position. However, it was found that most of the reviewed studies used PAS $(5,11,13,15,18,19,23,25,26,29-31,33,35,37)$. Furthermore, it was found that most studies used methods of photography as a way for analysis. ${ }^{(5-11,13,15,18-27,29-33,35,37)}$

In relation with the picture, a very important issue that must be observed for the comparison of data from different studies is the distance of the tripod in relation to the evaluated individual. It was observed that there is no standardization of distance, while in methods that used PAS ${ }^{(5)}$ and photogrammetry ${ }^{(9)}$ was used a distance of $3 \mathrm{~m}$, in photography ${ }^{(21)}$ was used $4 \mathrm{~m}$ and in biophotogrammetry ${ }^{(32)}$ was used $2.2 \mathrm{~m}$.

It was observed that most of the studies that performed a quantitative analysis illustrated average and standard deviation of angles (5,7,14,18-20,26,29,32,35); others studies showed mean, standard deviation, median and percentiles of the angles ${ }^{(8,28)}$, in addition to these variables, some showed the frequency ${ }^{(15)}$; other presented only median and percentile ${ }^{(23)}$; other used average, standard deviation, median, minimum and maximum ${ }^{(25)}$; other study used variable, average and standard deviation ${ }^{(31)}$; other used measured angles ${ }^{(33)}$; other study showed average, median and standard deviation of measured angles ${ }^{(37)}$. Only one study used the Dendogram to illustrate the results ${ }^{(11)}$.

In relation to studies that perform a qualitative description, most made the description of postural changes found, others showed the frequency of postural changes $(6,9,10,12,17,27)$, other studies used the frequency of changes and the descriptive analysis ${ }^{(21,36)}$, others just used the descriptive analysis of changes $(13,22,24,30,34)$, only two studies used the classification in regular, moderate and severe ${ }^{(16,28)}$. It was observed interested studies to assess the posture of children ${ }^{(10,12,16,26,28)}$, of teens $(9,12,15-17,25)$, of adults $(5,7,8,11,13,14,18-23,30-34,36,37)$ and elderly $(6,24,27,29,36)$. Among adults it should be noted the interest in investigating women who had mastectomies ${ }^{(18,36,37)}$ and athletes ${ }^{(21-22)}$.

Based on this study, we observed heterogeneity in research related to body posture, making it difficult to compare data between studies. It indicates the necessity of choosing a standard method that is accessible to physiotherapists and that meets the needs of providing data reliably. Furthermore, the presentation form of results also requires a standardization in order to enable and facilitate comparison between evaluations performed in different studies. Seeing the importance of postural evaluation in order to prevent and monitor and objectively the evolution of postural correction treatments.

\section{CONCLUSION}

Based on this study, it was found that different methods are used for the evaluation of body posture, among which Postural Assessment Software (PAS) was the most used. In relation to the presentation form of postural changes, the average and standard deviation were the most used. It is suggested the standardization of evaluations to facilitate comparison between the data from different studies.

\section{AUTHOR'S CONTRIBUTION}

XBP: Systematic review and writing of the article; ECWM: Systematic review and writing of the article.

\section{COMPETING INTERESTS}

The authors declare that they have no conflicts of interest in the research.

\section{AUTHOR DETAILS}

${ }^{1}$ Universidade Federal de Santa Maria (UFSM), Santa Maria (RS), Brazil.

\section{REFERENCES}

1. Braccialli LMP, Vilarta R. Aspectos a serem considerados na elaboração de programas de prevenção e orientação de problemas posturais. Rev. Paul. Educ. Fís. 2000;14(1):16-28.

2. Magee DJ. Avaliação musculoesquelética. 4a ed. Barueri, São Paulo: Manole; 2005.

3. Kendall FP, McCreary EK, Provance PG, Rod MM. Músculos: provas e funções: com postura e dor.4a ed. São Paulo: Manole; 1995.

4. Kapandji Al. Fisiologia articular: esquemas comentados de mecânica humana. 5a ed. São Paulo: Manole; 1990.

5. Moraes GFS, Antunes AP, Rezende ES, Oliveira PCR. Uso de diferentes tipos de calçados não interfere na postura ortostática de mulheres hígidas. Fisioter. mov. (Impr.) 2010;23(4):565-574.

6. Lima HCO, Aguiar JB, Paredes PFM, Gurgel LA. Avaliação dos benefícios da ginástica localizada sobre a postura e a flexibilidade de mulheres na terceira idade. Rev. bras. Educ. Fís. Esporte. 2010;24(4):525-34.

7. Bigaton DR, Silvério KCA, Berni KCS, Distefano G, Forti F, Guirro RRJ. Postura crânio-cervical em mulheres disfônicas. Rev. soc. bras. fonoaudiol. 2010;15(3):329-334.

8. Coelho Júnior NA, Gazzola JM, Gabilan YPL, Mazzetti KR, Perracini MR, Ganança FF. Alinhamento de cabeça e ombros em pacientes com hipofunção vestibular unilateral. Rev Bras Fisioter. 2010;(14)4:330-6.

9. Graup S, Santos SG, Moro ARP. Estudo descritivo de alterações posturais sagitais da coluna lombar em escolares da rede federal de ensino de Florianópolis. Rev. bras. ortop. 2010;(45)5:453-459.

10. Molinari VS, Massuia FAO. Análise da postura e apoio plantar de crianças portadoras de Síndrome de Down consideradas obesas. J Health Sci Inst. 2010;28(4):345-7. 
11. Okama LO, Queiroz PD, Spina LR, Miranda MBL, Curtarelli MB, Júnior MF et al. Avaliação funcional e postural nas distrofias musculares de Duchenne e Becker. Conscientiae saúde (Impr.); 2010;9(4):649-658.

12. Vasconcelos GAR, Fernandes PRB, Oliveira DA, Cabral ED, Silva LVC. Avaliação postural da coluna vertebral em escolares surdos de 7-21 years. Fisioter. Mov. 2010;23(3):371-380.

13. Ferreira LP, Penha PJ, Caporossi C, Fernandes ACN. Professores universitários: descrição de características vocais e posturais. Distúrb Comum. 2011;23(1):43-49.

14. Machado PG, Hammes MH, Cielo CA, Rodrigues AL. Os hábitos posturais e o comportamento vocal de profissionais de educação física na modalidade de hidroginástica. Rev. CEFAC. 2011;13(2):299-313.

15. Meereis ECW, Favretto $C$, Bernardi CL, Peroni ABF, Mota CB. Análise de tendências posturais em praticantes de balé clássico. R. da Educação Física/UEM Maringá. 2011;22(1):27-35.

16. Conti PBM, Sakano E, Ribeiro MAGO, Schivinski CIS, Ribeiro JD Avaliação da postura corporal em crianças e adolescentes respiradores orais. J. Pediatr. 2011;(87)4:357-363.

17. Souza Melo R, Silva PWA, Silva LVC, Toscano CFS. Avaliação postural da coluna vertebral em crianças e adolescentes com deficiência auditiva. Arquivos Int. Otorrinolaringol. (Impr.) 2011;15(2):195-202.

18. Melo MSI, Maia JN, Silva DAL, Carvalho CC. Avaliação Postural em Pacientes Submetidas à Mastectomia Radical Modificada por meio da Fotogrametria Computadorizada. Rev. Bras. Cancerol. 2011;57(1):39-48.

19. Rossi LP, Brandalize M, Gomes ARS. Efeito agudo da técnica de reeducação postural global na postura de mulheres com encurtamento da cadeia muscular anterior. Fisioter. Mov. 2011;(24)2:255-263.

20. Candotti CT, Nunes SEB, Noll M, Freitas K, Macedo $\mathrm{CH}$. Efeitos de um programa de educação postural para crianças e adolescentes após oito meses de seu término. Rev. paul. pediatr.2011;29(4):577-583.

21. Meliscki GA, Monteiro LZ, Giglio CA. Avaliação postural de nadadores e sua relação com o tipo de respiração. Fisioter. Mov. 2011;24(4):721-728.

22. Veiga PHA, Daher CRM, Morais MFF. Alterações posturais e flexibilidade da cadeia posterior nas lesões em atletas de futebol de campo. Rev. Bras. Ciênc. Esporte (Impr.) 2011; 33(1):235-248.

23. Pachioni CAS, Ferrante JA, Panissa TSD, Ferreira DMA, Ramos D, Moreira GL et al. Avaliação postural em pacientes com doença pulmonar obstrutiva crônica. Fisioter. Pesqui. 2011;18(4):341-5.

24. Gasparotto LPR, Reis CCl, Ramos LR, Santos JFQ. Autoavaliação da postura por idosos com e sem hipercifose torácica. Ciênc. saúde coletiva. 2012;17(3):719-722.

25. Bosso LR, Golias ARC. A postura de atletas de ginástica rítmica: análise através da fotometria. Rev Bras Med Esporte. 2012;18(5):333-337.

26. Morimoto T, Karolczak APB. Associação entre as alterações posturais e a respiração bucal em crianças. Fisioter. mov. 2012;25(2):379-388.
27. Porto F, Espinosa G, Vivian RC, Itaborahy AS, Montenegro RA, Farinatti PTV et al. O exercício físico influencia a postura corporal de idosas? Motriz: rev. educ. fis. 2012;18(3):487-484.

28. Vieira KR, Lichtblau M, Gonçalves RM, Schivinski CIS. Repercussões no sistema respiratório e na postura de crianças com história de displasia broncopulmonar. Pediatria Moderna. 2013;49(10):427-432.

29. Tavares GMS, Rocha TR, Santo CCE, Piazza L, Sperandio FF, Mazo GZ et al. Características posturais de idosos praticantes de atividade física. Scientia Medica (Porto Alegre). 2013;23(4):244-250.

30. Simão SSS, Romero VU, Baraldil K, Oda AL, Viana CF, Chiappetta ALML et al. Avaliação clínica da relação entre postura, respiração e deglutição em paciente pós-acidente vascular cerebral na fase crônica: relato de caso. Rev. CEFAC. 2013;15(5):1371-1378.

31. Sinzato CR, Taciro C, Pio CA, Toledo AM, Cardoso JR, Carregaro RL. Efeitos de 20 sessões do método Pilates no alinhamento postural e flexibilidade de mulheres jovens: estudo piloto. Fisioter Pesq. 2013;20(2):143-150.

32. Barbosa JAN, Amorim MHC, Zandonade E, Delaprane ML. Avaliação da postura corporal em mulheres com câncer de mama. Rev Bras Ginecol Obstet. 2013;35(5):215-20.

33. Borges CS, Fernandes LFRM, Bertoncello D. Correlação entre alterações lombares e modificações no arco plantar em mulheres com dor lombar. Acta ortop. bras. 2013;21(3):135-138

34. Colpo IMS, Daronco LSE, Balsan LAG. Avaliação postural, dor e aptidão física de praticantes de hidroginástica. Rev. Dor. 2013;14(1):35-38.

35. Azato FK, Castillo DB, Coelho TMK, Taciro C, Pereira PZ, Zomerfeld V et al. Influência do tratamento das desordens temporomandibulares na dor e na postura global. Rev. Dor. 2013;14(4):280-283.

36. Haddad CAS, Saad M, Perez MCJ, Júnior FM. Avaliação da postura e dos movimentos articulares dos membros superiores de pacientes pósmastectomia e linfadenectomia. Einstein. 2013;11(4):426-434.

37. Gimenes RO, Tacani MP, Junior SAG, Campos CM, Batista AN. Fisioterapia aquática e de solo em grupo na postura de mulheres mastectomizadas. J Health Sci Inst. 2013;31(1):79-83.

38. Braz RG, Goes FPC, Carvalho GA. Confiabilidade e validade de medidas angulares por meio do Software para Avaliação Postural. Fisioter. Mov. 2008;21(3):117-126

39. Souza JA, Pasinato F, Basso D, Corrêa ECR, Silva AMT. Biofotogrametria confiabilidade das medidas do protocolo do Software para Avaliação Postural (SAPO). Rev Bras Cineantropom Desempenho Hum. 2011;13(4):299-305.

40. Kisner C, Colby LA. Exercicios terapêuticos: fundamentos e técnicas. 5a ed. Barueri: Manole; 2009.

41. New York (State). Division of Health. The New York State physical fitness test for boys and girls, grades 4-12: a manual for teachers of physical education. The University of the State of New York, 1966. 